\title{
UTILIZATION OF MATERNAL HEALTH CARE SERVICES IN UTTARAKHAND: COMPARATIVE STUDY BETWEEN TWO DIVISIONS: KUMAUN AND GARHWAL
}

Shubham Pandey ${ }^{1}$, Ankit Singh ${ }^{* 2}$, Ashish Gaur ${ }^{3}$.

${ }^{1}$ Assistant professor, Department of Biostatistics, Himalayan Institute of Medical Sciences, SRHU, Dehradun, India.

${ }^{* 2}$ Lecturer, Department of Biostatistics, Himalayan Institute of Medical Sciences, SRHU, Dehradun, India.

${ }^{3}$ Data Manager cum Analyst, Department of Biostatistics, Himalayan Institute of Medical Sciences, SRHU, Dehradun, India.

\section{ABSTRACT}

Background: Maternal mortality remains a biggest setback in developing nations like India. Almost $90 \%$ of maternal deaths can be prevented by timely intervention, antenatal care acts as an effective tool to reduce both maternal and infant mortality. The objective of this study is to assess the utilization of antenatal care services in two divisions of Uttarakhand: Kumaun and Garhwal.

Materials and Methods: The study was carried out using secondary data source i.e. NFHS-4 data of Uttarakhand which is divided into two regions, Garhwal and Kumaun. Statistical test i.e. Z-test is used for the comparison between two regions and within inter districts of Uttarakhand.

Result: The results of this study indicates that between the two regions i.e Kumaun has better utilization of maternal health care facilities. Nainital district recorded best and Pithoragarh district recorded the least utilization of ANC services in Kumaun division. In Garhwal division, district Chamoli and Dehradun recorded highest utilization of maternal health care services whereas Rudraprayag and Tehri-Garhwal had discouraging statistics.

Conclusion: Uttarakhand has immensely progressed in terms of maternal health in recent times; still there are some key areas that require immediate attention. Certain districts in both Garhwal and Kumaun division need assistance to improve maternal health care seeking behavior amongst the mother and the family. Dissemination of information and benefits regarding the utilization of ANC services should be encouraged to achieve a reduction in maternal mortality.

KEY WORDS: Ante Natal Checkup (ANC), Uttarakhand, Kumaun, Garhwal.

Address for correspondence: Ankit Singh, Lecturer, Department of Biostatistics, Himalayan Institute of Medical Sciences, Swami Rama Himalayan University, jolly grant, Dehradun, India.

E-Mail: shubhampandey@srhu.edu.in, ankitbiostat@gmail.com

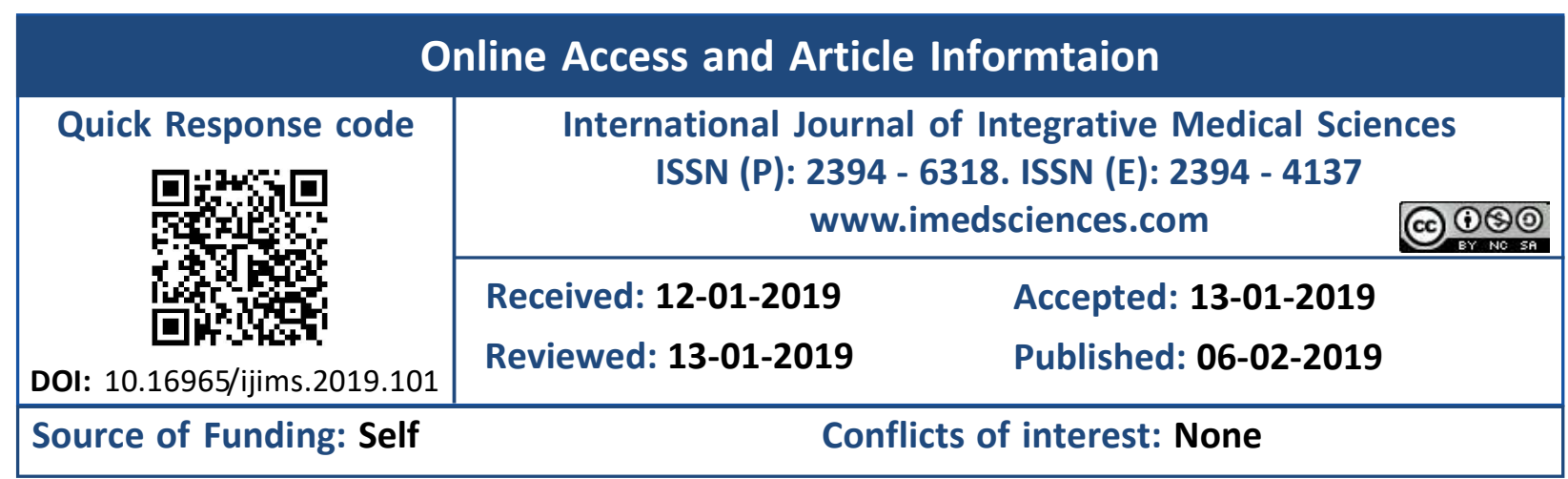

\section{BACKGROUND}

Maternal and child mortality plays a significant role in the country's overall health status. The use of maternal health care services not only improves the maternal and child health but also improves the reproductive health of women [1]. Maternal care and child health are important for the well-being of the next generation; it can help to predict future public health challenges for 
families, communities, and the health care system. Maternal and child health care service is defined as "promoting, preventing, therapeutic or rehabilitation facility or care for the mother and child". Its goal is to reduce mortality and morbidity among mothers, infants, and preschool children. The major direct causes of maternal morbidity and mortality include hemorrhage, infection, high blood pressure, unsafe abortion, and obstructed labour [2].

Antenatal care is the routine health control of presumed healthy pregnant women without symptoms (screening), in order to diagnose diseases or complicating obstetric conditions without symptoms and to provide information about lifestyle, pregnancy, and delivery. The components of ANC include risk identification; prevention and management of pregnancy-related or concurrent diseases; and health education and health promotion $[3,4]$. The utilization of maternal health care services varies with the socioeconomic characteristics of the population. Women in higher socioeconomic strata tend to exhibit patterns of more frequent use of maternal health services than women in lower socioeconomic strata [5]. Factors like a place of residence, religion, and standard of living of the household are other few socio-economic factors that are responsible for maternal health care service seeking behavior [6].

Uttarakhand is stated as Low Performing State under JSY [7]. Hence, it becomes essential to analyze and study the utilization of maternal health services in Uttarakhand and identify the regions with poor performance. This will provide direction to the policy makers and Government to effectively employ its programmes under Janani Shishu Suraksha Karyakram (JSSK).

The present study focuses on developing indicators to measure the adequacy of antenatal care. In particular, this study aims to describe the adequacy of antenatal care for women in the context of a population in two different divisions of Uttarakhand: Garhwal and Kumaun.

\section{Objectives}

1. To extrude the data on maternal health care services and compare it region wise in Uttarakhand.
2. To compare the maternal health care services between two regions of Uttarakhand i.e. Garhwal region and Kumaun region.

3. To compare the maternal health care services in inter districts of Garhwal region.

4. To compare the maternal health care services in inter districts of Kumaun region.

\section{MATERIALS AND METHODS}

The study was conducted using the secondary data source of Uttarakhand available from $\mathrm{Na}$ tional Family Health Surveys-4 conducted in 2015-2016. NFHS-4 fieldwork for Uttarakhand was started from 30, January 2015 to 19, July 2015 by Institute of Health Management Research (IIHMR University, Jaipur) and gathered information from 15,171 households, which consists of 17,300 women and 1,994 men. Fact sheets for each district of Uttarakhand were also utilized for the studies $[8,9]$.

Statistical Analysis: The $Z$ test for two-population proportion was applied for different study indicators. P-value is calculated and if $p>0.05$, $\mathrm{H}_{0}$ is accepted and if $\mathrm{p}<0.05$, then $\mathrm{H}_{0}$ is rejected at $5 \%$ of level of significance.

\section{RESULTS}

The status of maternal health services of Uttarakhand and its region under study is presented in

Table 1. In terms of iron-folic acid supplementation ( $p$-value 0.0226), complete antenatal care ( $p$-value 0.0041) and full checkup of children after birth ( $p$-value 0.0088), significant differences are observed between the two divisions: Kumaun and Garhwal. Kumaun has the higher proportion of mothers who took iron-folic acid supplementation for 100 or more days while pregnant ( $p$-value 0.048).

The status of maternal health services in Kumaun region is represented in Table $\mathbf{2}$, overall, maternal health services are best in Nainital district. Not all the other districts are lagging behind too much in terms of health facilities and outcome. Only Pithoragarh district requires little more attention. Mothers who had an antenatal checkup in the first trimester have the highest proportion in Nainital ( $p$-value 0.0). Nainital ( $p$-value 0.0 ) observed the maximum of the proportion of mothers who had at least four antenatal care 
Table 1: Distribution of Maternal Health care services according to regions and its comparison with State.

\begin{tabular}{|c|c|c|c|c|c|c|}
\hline $\begin{array}{c}\text { Maternity Care (for last birth in the } 5 \\
\text { years before the survey) }\end{array}$ & KUMAUN & GARHWAL & UTTARAKHAND & $\begin{array}{c}\text { K vs. G } \\
\text { [p-value] }\end{array}$ & $\begin{array}{c}\text { K vs. U } \\
\text { [p-value] }\end{array}$ & $\begin{array}{c}\text { G vs. U } \\
\text { [p-value ] }\end{array}$ \\
\hline $\begin{array}{l}\text { Mothers who had antenatal check-up in } \\
\text { the first trimester (\%) }\end{array}$ & 50.9 & 54.03 & 53.5 & 0.164 & 0.246 & 0.825 \\
\hline $\begin{array}{l}\text { Mothers who had at least } 4 \text { antenatal care } \\
\text { visits (\%) }\end{array}$ & 30.32 & 27.31 & 30.9 & 1.138 & 0.771 & 0.076 \\
\hline $\begin{array}{l}\text { Mothers whose last birth was protected } \\
\text { against neonatal tetanus (\%) }\end{array}$ & 91.65 & 93.27 & 91.4 & 0.149 & 0.872 & 0.109 \\
\hline $\begin{array}{l}\text { Mothers who consumed iron folic acid for } \\
100 \text { days or more when they were } \\
\text { pregnant (\%) }\end{array}$ & 28.8 & 24.31 & 24.9 & 0.022 & 0.048 & 0.756 \\
\hline Mothers who had full antenatal care (\%) & 13.58 & 9.54 & 11.5 & 0.004 & 0.155 & 0.144 \\
\hline $\begin{array}{l}\text { Registered pregnancies for which the } \\
\text { mother received Mother and Child } \\
\text { Protection (MCP) card (\%) }\end{array}$ & 95.05 & 94.81 & 93.4 & 0.841 & 0.126 & 0.183 \\
\hline $\begin{array}{l}\text { Mothers who received postnatal care from } \\
\text { a doctor/nurse/LHV/ANM/midwife/other } \\
\text { health personnel within } 2 \text { days of delivery } \\
\text { (\%) }\end{array}$ & 52.18 & 54.47 & 54.8 & 0.303 & 0.242 & 0.896 \\
\hline $\begin{array}{l}\text { Mothers who received financial assistance } \\
\text { under Janani Suraksha Yojna (JSY) for } \\
\text { births delivered in an institution (\%) }\end{array}$ & 59.1 & 59.29 & 49.4 & 0.928 & 0.001 & 0.001 \\
\hline $\begin{array}{l}\text { Children born at home who were taken to } \\
\text { a health facility for check-up within } 24 \\
\text { hours of birth (\%) }\end{array}$ & 1.03 & rra $1.97 e$ & $\mathrm{Meg}^{2.4}$ & 0.065 & 0.015 & 0.541 \\
\hline $\begin{array}{l}\text { Children who received a health check after } \\
\text { birth from a doctor/nurse/LHV/ANM/ } \\
\text { midwife/other health personnel within } 2 \\
\text { days of birth (\%) }\end{array}$ & 16.68 & & 19.3 & 0.008 & 0.131 & 0.267 \\
\hline
\end{tabular}

Table 2: Distribution of Maternal Health Care Services in Kumaun region and its comparison with its corresponding districts.

\begin{tabular}{|c|c|c|c|c|c|c|c|}
\hline $\begin{array}{c}\text { Maternity Care(for last birth in the } 5 \text { years } \\
\text { before the survey) }\end{array}$ & KUMAUN & ALM & BAG & CHA & N.TAL & PITH & UDSN \\
\hline $\begin{array}{l}\text { Mothers who had antenatal check-up in the first } \\
\text { trimester (\%) }\end{array}$ & 50.9 & $\begin{array}{c}57.7 \\
(0.002)\end{array}$ & $\begin{array}{c}42 \\
(0.001)\end{array}$ & $\begin{array}{c}43.7 \\
(0.001)\end{array}$ & $\begin{array}{c}65.7 \\
(0.001)\end{array}$ & $\begin{array}{c}49.9 \\
(0.652)\end{array}$ & $\begin{array}{c}46.4 \\
(0.044)\end{array}$ \\
\hline $\begin{array}{l}\text { Mothers who had at least } 4 \text { antenatal care visits } \\
\text { (\%) }\end{array}$ & 30.32 & $\begin{array}{c}31.7 \\
(0.496)\end{array}$ & $\begin{array}{c}23.4 \\
(0.001)\end{array}$ & $\begin{array}{c}29 \\
(0.522)\end{array}$ & $\begin{array}{c}40.4 \\
(0.001)\end{array}$ & $\begin{array}{c}30.8 \\
(0.810)\end{array}$ & $\begin{array}{c}26.6 \\
(0.067)\end{array}$ \\
\hline $\begin{array}{l}\text { Mothers whose last birth was protected against } \\
\text { neonatal tetanus (\%) }\end{array}$ & 91.65 & $\begin{array}{c}91.4 \\
(0.872)\end{array}$ & $\begin{array}{c}92.1 \\
(0.681)\end{array}$ & $\begin{array}{c}95.2 \\
(0.001)\end{array}$ & $91.6(1)$ & $\begin{array}{c}92.7 \\
(0.362)\end{array}$ & $\begin{array}{c}86.9 \\
(0.007)\end{array}$ \\
\hline $\begin{array}{l}\text { Mothers who consumed iron folic acid for } 100 \\
\text { days or more when they were pregnant (\%) }\end{array}$ & 28.8 & $\begin{array}{c}35.7 \\
(0.001)\end{array}$ & $\begin{array}{c}23.6 \\
(0.008)\end{array}$ & $\begin{array}{c}27.3 \\
(0.453)\end{array}$ & $\begin{array}{c}40.9 \\
(0.001)\end{array}$ & $\begin{array}{c}28.7 \\
(0.960)\end{array}$ & $\begin{array}{c}16.6 \\
(0.001)\end{array}$ \\
\hline Mothers who had full antenatal care (\%) & 13.58 & $\begin{array}{c}18.7 \\
(0.001)\end{array}$ & $\begin{array}{c}10.7 \\
(0.047)\end{array}$ & $\begin{array}{c}11.1 \\
(0.089)\end{array}$ & $\begin{array}{c}20.5 \\
(0.001)\end{array}$ & $\begin{array}{c}14.7 \\
(0.477)\end{array}$ & $\begin{array}{c}5.8 \\
(0.001)\end{array}$ \\
\hline $\begin{array}{l}\text { Registered pregnancies for which the mother } \\
\text { received Mother and Child Protection (MCP) card } \\
\text { (\%) }\end{array}$ & 95.05 & $\begin{array}{c}99.5 \\
(0.001)\end{array}$ & $\begin{array}{c}95.7 \\
(0.459)\end{array}$ & $\begin{array}{c}97.3 \\
(0.007)\end{array}$ & $\begin{array}{c}93.7 \\
(0.207)\end{array}$ & $\begin{array}{c}94.9 \\
(0.920)\end{array}$ & $\begin{array}{c}89.2 \\
(0.001)\end{array}$ \\
\hline $\begin{array}{l}\text { Mothers who received postnatal care } \\
\text { fromdoctor/nurse/LHV/ANM/midwife/other } \\
\text { health personnel within } 2 \text { days of delivery (\%) }\end{array}$ & 52.18 & $\begin{array}{c}58 \\
(0.009)\end{array}$ & $\begin{array}{c}42.1 \\
(0.001)\end{array}$ & $\begin{array}{c}50.7 \\
(0.502)\end{array}$ & $\begin{array}{c}59.5 \\
(0.001)\end{array}$ & $\begin{array}{c}56.4 \\
(0.048)\end{array}$ & $\begin{array}{c}46.4 \\
(0.009)\end{array}$ \\
\hline $\begin{array}{l}\text { Mothers who received financial assistance under } \\
\text { Janani Suraksha Yojana (JSY) for births delivered } \\
\text { in an institution (\%) }\end{array}$ & 59.1 & $\begin{array}{c}60.8 \\
(0.435)\end{array}$ & $\begin{array}{c}76.8 \\
(0.001)\end{array}$ & $\begin{array}{c}50.3 \\
(0.001)\end{array}$ & $\begin{array}{c}44.3 \\
(0.001)\end{array}$ & $\begin{array}{c}81.6 \\
(0.001)\end{array}$ & $\begin{array}{c}40.8 \\
(0.001)\end{array}$ \\
\hline $\begin{array}{l}\text { Children born at home who were taken to a } \\
\text { health facility for check-up within } 24 \text { hours of } \\
\text { birth (\%) }\end{array}$ & 1.03 & $\begin{array}{c}0 \\
(0.001)\end{array}$ & $\begin{array}{c}2.8 \\
(0.003)\end{array}$ & $\begin{array}{c}0 \\
(0.001)\end{array}$ & $\begin{array}{c}2.3 \\
(0.022)\end{array}$ & $\begin{array}{c}0 \\
(0.001)\end{array}$ & $\begin{array}{c}1.1 \\
(0.825)\end{array}$ \\
\hline $\begin{array}{l}\text { Children who received a health check after birth } \\
\text { from a doctor/nurse/LHV/ANM/ midwife/other } \\
\text { health personnel within } 2 \text { days of birth (\%) }\end{array}$ & 16.68 & $\begin{array}{c}29.6 \\
(0.001)\end{array}$ & $\begin{array}{c}14.8 \\
(0.242)\end{array}$ & $\begin{array}{c}10.8 \\
(0.001)\end{array}$ & $\begin{array}{c}18.4 \\
(0.317)\end{array}$ & $\begin{array}{c}12 \\
(0.002)\end{array}$ & $\begin{array}{c}14.5 \\
(0.173)\end{array}$ \\
\hline
\end{tabular}


Table 3: Distribution of Maternal Health Care Services in Garhwal region and its comparison with its corresponding districts.

\begin{tabular}{|c|c|c|c|c|c|c|c|c|}
\hline $\begin{array}{c}\text { Maternity Care } \\
\text { (for last birth in the } 5 \text { years before the survey) }\end{array}$ & GHW & DND & HW & TEHRI & Ut.Kh & $\mathbf{C H}$ & PAURI & R.PRAYAG \\
\hline $\begin{array}{l}\text { Mothers who had antenatal check-up in the first } \\
\text { trimester (\%) }\end{array}$ & 54.03 & $\begin{array}{c}71.9 \\
(0.001)\end{array}$ & $\begin{array}{c}42.6 \\
(0.001)\end{array}$ & $\begin{array}{c}53.8 \\
(0.928)\end{array}$ & $\begin{array}{c}43.8 \\
(0.001)\end{array}$ & $\begin{array}{c}49.2 \\
(0.031)\end{array}$ & $\begin{array}{c}61.4 \\
(0.001)\end{array}$ & $\begin{array}{c}55.5 \\
(0.502)\end{array}$ \\
\hline Mothers who had at least 4 antenatal care visits (\%) & 27.31 & $\begin{array}{c}47.1 \\
(0.001)\end{array}$ & $\begin{array}{c}24.2 \\
(0.111)\end{array}$ & $\begin{array}{c}23.8 \\
(0.073)\end{array}$ & $\begin{array}{c}22.2 \\
(0.008)\end{array}$ & $\begin{array}{c}20.3 \\
(0.001)\end{array}$ & $\begin{array}{c}36.4 \\
(0.001)\end{array}$ & $\begin{array}{c}17.2 \\
(0.001)\end{array}$ \\
\hline $\begin{array}{l}\text { Mothers whose last birth was protected against } \\
\text { neonatal tetanus (\%) }\end{array}$ & 93.27 & $\begin{array}{c}97.5 \\
(0.001)\end{array}$ & $\begin{array}{c}87.9 \\
(0.001)\end{array}$ & $\begin{array}{c}92.6 \\
(5.541)\end{array}$ & $\begin{array}{c}93.2 \\
(0.928)\end{array}$ & $\begin{array}{c}90.7 \\
(0.032)\end{array}$ & $\begin{array}{c}95.6 \\
(0.024)\end{array}$ & $\begin{array}{c}95.4 \\
(0.042)\end{array}$ \\
\hline $\begin{array}{l}\text { Mothers who consumed iron folic acid for } 100 \text { days } \\
\text { or more when they were pregnant (\%) }\end{array}$ & 24.31 & $\begin{array}{c}29.2 \\
(0.013)\end{array}$ & $\begin{array}{c}19.1 \\
(0.004)\end{array}$ & $\begin{array}{c}24.4 \\
(0.96)\end{array}$ & $\begin{array}{c}28 \\
(0.06)\end{array}$ & $\begin{array}{c}18.8 \\
(0.002)\end{array}$ & $\begin{array}{c}26.3 \\
(0.303)\end{array}$ & $\begin{array}{c}24.4 \\
(0.96)\end{array}$ \\
\hline Mothers who had full antenatal care (\%) & 9.54 & $\begin{array}{c}18.9 \\
(0.001)\end{array}$ & $\begin{array}{c}7.6 \\
(0.128)\end{array}$ & $\begin{array}{c}7.2 \\
(0.062)\end{array}$ & $\begin{array}{c}9.6 \\
(0.936)\end{array}$ & $\begin{array}{c}5.9 \\
(0.002)\end{array}$ & $\begin{array}{c}11.9 \\
(0.081)\end{array}$ & $\begin{array}{c}5.7 \\
(0.001)\end{array}$ \\
\hline $\begin{array}{l}\text { Registered pregnancies for which the mother } \\
\text { received Mother and Child Protection (MCP) card } \\
\text { (\%) }\end{array}$ & 94.81 & $\begin{array}{c}94.3 \\
(0.624)\end{array}$ & $\begin{array}{c}89.7 \\
(0.001)\end{array}$ & $\begin{array}{c}98.1 \\
(0.001)\end{array}$ & $\begin{array}{c}92.5 \\
(0034)\end{array}$ & $\begin{array}{c}97.8 \\
(0.001)\end{array}$ & $\begin{array}{c}95.1 \\
(0.756)\end{array}$ & $\begin{array}{c}96.2 \\
(0.131)\end{array}$ \\
\hline $\begin{array}{l}\text { Mothers who received postnatal care from a } \\
\text { doctor/nurse/LHV/ANM/midwife/other health } \\
\text { personnel within } 2 \text { days of delivery (\%) }\end{array}$ & 54.47 & $\begin{array}{c}68.6 \\
(0.001)\end{array}$ & $\begin{array}{c}52.7 \\
(0.417)\end{array}$ & $\begin{array}{c}52.7 \\
(0.417)\end{array}$ & $\begin{array}{c}45.6 \\
(0.001)\end{array}$ & $\begin{array}{c}47.9 \\
(0.003)\end{array}$ & $\begin{array}{c}56.3 \\
(0.001)\end{array}$ & $\begin{array}{c}57.5 \\
(0.177)\end{array}$ \\
\hline $\begin{array}{l}\text { Mothers who received financial assistance under } \\
\text { Janani Suraksha Yojana (JSY) for births delivered in } \\
\text { an institution (\%) }\end{array}$ & $\begin{array}{r}59.29 \\
0.10 \\
\end{array}$ & $\begin{array}{c}50 \\
(0.001)\end{array}$ & $\begin{array}{c}30.2 \\
(0.001) \\
\end{array}$ & $\begin{array}{c}64.9 \\
(0.009)\end{array}$ & $\begin{array}{c}79.2 \\
(0.001)\end{array}$ & $\begin{array}{c}67.1 \\
(0.001)\end{array}$ & $\begin{array}{c}60.9 \\
(0.465)\end{array}$ & $\begin{array}{c}62.7 \\
(0.118)\end{array}$ \\
\hline $\begin{array}{l}\text { Children born at home who were taken to a health } \\
\text { facility for check-up within } 24 \text { hours of birth (\%) }\end{array}$ & & $\begin{array}{c}6.3 \\
(0.0)\end{array}$ & $\begin{array}{c}4.2 \\
(0.00452)\end{array}$ & $\begin{array}{c}0 \\
(0.0)\end{array}$ & $\begin{array}{c}1.2 \\
(0.15272)\end{array}$ & $\begin{array}{c}1 \\
(0.065)\end{array}$ & * & $\begin{array}{c}1.1 \\
(0.103)\end{array}$ \\
\hline $\begin{array}{l}\text { Children who received a health check after birth } \\
\text { from a doctor/nurse/LHV/ANM/ midwife/other } \\
\text { health personnel within } 2 \text { days of birth (\%) }\end{array}$ & 21.3 & $31(0.00)$ & $\begin{array}{c}16.2 \\
(0.003)\end{array}$ & $\begin{array}{c}10.7 \\
(0.001)\end{array}$ & $\begin{array}{c}14.4 \\
(0.001)\end{array}$ & $\begin{array}{c}30.9 \\
(0.001)\end{array}$ & $\begin{array}{c}15.7 \\
(0.001)\end{array}$ & $\begin{array}{c}30.2 \\
(0.001)\end{array}$ \\
\hline
\end{tabular}

visits along with Bageshwar ( $p$-value 0.0005). Iron-folic acid consumption for 100 or more days during pregnancy and full antenatal care is highest in Udham Singh Nagar and Nainital ( $p$-value 0.0).

Maternal health care services in Garhwal region is depicted in Table 3, Dehradun and Chamoli districts have best maternal health services in the division while Rudraprayag and Tehrigarhwal has a deplorable state. The high proportion of mothers who has an antenatal checkup in the first trimester are present in Dehradun, Haridwar, and Uttarkashi (p-value 0.0) succeeded by Pauri-Garhwal ( $p$-value 0.0008 ) and Chamoli ( $p$-value 0.0315). Mothers who had at least four antenatal care visits have high proportion in Dehradun, Rudraprayag and Pauri Garhwal ( $p$ value 0.0). Dehradun and Haridwar have the highest proportion of mothers whose last birth was protected against neonatal tetanus ( $p$-value 0.001).

\section{DISCUSSION}

The results indicate that there were significant differences in utilization of maternal health care services between the two divisions. Overall, Kumaun fared much better, which could be associated to high literacy levels in the district, the relationship between literacy and utilization of maternal health care has been supported by various researches [10,11]. Almora, Bageshwar, Champawat, Nainital and Udham Singh Nagar had better usage of maternal healthcare facilities.

Nainital district recorded a significant proportion of women utilizing maternal healthcare facilities like an antenatal checkup in the first trimester, at least four antenatal care visits, iron folic-acid supplementation for 100 or more days etc. The high rate of literacy in the district corelates the use of maternal health services. Literacy directly relates to the awareness amongst the women, thus exposing them to information and improving health-seeking behavior $[10,11]$. Though Pithoragarh stands $3^{\text {rd }}$ in terms of literacy rates amongst all the districts in Uttarakhand, it has minimum utilization of maternal health care services Major factors like, inaccessibility and harsh environment are responsible for such discouraging statistics. The shortfall of both medical and paramedical workforce is particularly acute in district Pithoragarh. Apart from that, poor quality of health facilities and low knowledge amongst ANC has a negative impact on the women of the district [12]. 
Amongst the districts in Garhwal region, Chamoli and Dehradun had satisfactory results, which again could be attributed to high literacy rates in the districts $[10,11]$. Awareness amongst mothers to utilize maternal health care can help in pleasant motherhood experience. Both the districts recorded high percentage of women seeking antenatal checkup in first trimester, at least four antenatal care visits, iron folic acid supplementation for 100 or more days etc.

In spite of implementation of various programmes like Janani Suraksha Yojana, JSSK etc., Tehri- Garhwal had discouraging statistics, where minimum maternal care seeking behavior was observed. Lack of awareness and attention among the common masses is a major reason, as the state is far behind the acceptable literacy levels [10]. Lack of human resources especially, senior officials and specialists at the major facilities are responsible for such low maternal health care usage. Janani Surkasha Yojana is functional in the district, but there are issues regarding procedure of the sanctioning of the JSY payment in the district. In most of the facilities in the district were not aware about the correct method of issuing the cheque to the patients [13].

\section{CONCLUSION}

Utilization of maternal health care facility not only improves the health status of a region but also is an indication of awareness and attention amongst its people. This study offers a compelling justification on differences in utilization of maternal health care services between the two divisions of Uttarakhand. This study also highlights the problematic area that requires immediate intervention for remediation.

\section{REFERENCES}

[1]. Kifle, D., Azale, T., Gelaw, Y. A. and Melsew, Y. A. Maternal health care service seeking behaviors and associated factors among women in rural Haramaya District, Eastern Ethiopia: a triangulated community-based cross-sectional study Reproductive Health 2017;14:6.

[2]. The World Health Report. (2005). Mothers and children matter- so does their health. Geneva, Switzerland: WHO press.

[3]. WHO. (2016). WHO recommendations on antenatal care for a positive pregnancy experience. Geneva, Switzerland: WHO press.
[4]. Guidelines for Antenatal Care and Skilled Attendance at Birth by ANMs/LHVs/SNs (2010, April). O/o Maternal Health Division, Ministry of Health and Family Welfare, Government of India, New Delhi.

[5]. Dey, D. (2009). The Reproductive and Child Health $(\mathrm{RCH})$ status in West Bengal: Observations from NFHS surveys in 1992-93 and 1998-99. In: Adak, D. K., Chattopadhyay, A. and Bharati, P. (Eds.): People of Contemporary West Bengal. New Delhi: Mohit Publications.

[6]. Pandey, A., Mishra, P. and Ojha, A. (2002). An analysis of the child spacing effect of the utilization of maternal health care services in some selected states in India. In: Chandra, M., Pandey, A., Mishra, P. and Singh, U. (Eds.): Bio-statistical Aspects of Health and Epidemiology. Lucknow: Prakashan Kendra, pp: 39-46.

[7]. Janani Suraksha Yojana (2015). NHP CC DC.

[8]. International Institute for Population Sciences and ICF. National Family Health Survey (NFHS-4), India, 2015-2016: Uttarakhand. Mumbai, India: IIPS and Rockville, Maryland, USA: ICF, pages: 171; March2017.

[9]. Annual Health Survey (2010-11). Fact sheetUttarakhand. O/o the Registrar General \& Census Commissioner, Ministry of Home Affairs, Government of India, New Delhi.

[10]. Census of India 2011, Provisional Population Totals, Rural and Urban distribution of Uttarakhand series 6, Uttarakhand, India: Directorate of census operations, pages: 59; 2011.

[11]. Kateja, A. Role of female literacy in maternal and infant mortality decline. Social Change, 2007;37(2):29-39.

[12]. Quarterly monitoring report Uttarakhand. (AprilJune, 2013). NHSRC.

[13]. Sharma, S., Saini, J. and Goutam, N. Monitoring report of Tehri Garhwal district, Uttarakhand. PRC, IEG, pages: 37, September-October 2013.

How to cite this article: Shubham Pandey, Ankit Singh, Ashish Gaur. UTILIZATION OF MATERNAL HEALTH CARE SERVICES IN UTTARAKHAND: COMPARATIVE STUDY BETWEEN TWO DIVISIONS: KUMAUN AND GARHWAL. Int J Intg Med Sci 2019;6(1):760-764. DOI: 10.16965/ ijims.2019.101 